\title{
ACCIDENT INSURANCE FOR INFORMAL SECTOR WORKERS IN INDONESIA
}

\author{
Artikel Review
}

\author{
Author
}

Sri Denti On Madya1, Atik Nurwahyuni²

Public Health Faculty of University of Indonesia

University of Indonesia, Depok, West Java, Indonesia

Onmadya@yahoo.com¹,atikn.akk@gmail.com²

\begin{abstract}
S
Workplace accidents are unwanted and unexpected events that can cause loss of life and property. The Social Security Law in Indonesia mandates that Work Accident Guarantees be mandatory for every workforce in Indonesia. To see how work accident insurance for informal sector workers in Indonesia. This research was carried out by library study method. The subjects of this study are data in the form of articles and several source books related to the theme of the research, namely concerning workplace accidents and social security of informal sector workers in Indonesia. The number of work accidents, especially in the informal sector in Indonesia, still tends to be high, especially in construction work. Policies in the field of occupational health and safety $(K 3)$ still focus on formal sector workers rather than informal worker.
\end{abstract}

Keyword: work accident, social security, informal sector

\section{BACKGROUND}

The development of industrialization in Indonesia is growing very rapidly in both the formal and informal sectors, along with the increasing number of working people, in August 2017 reaching 192.08 million from a total population of 262.41 million. The informal sector absorbs most of the 35.92 million workers (29.68 percent). (BPS, 2017). The success of businesses in the informal sector is also supported by occupational health to overcome health problems due to work, thereby increasing welfare and productivity. This is in accordance with the Occupational Safety regulations which state that all workers have the right to the protection of their safety in carrying out work for welfare and increasing production and labor productivity (Kemenkes Rl 2012 in Aw Yusuf, 2017).

Workplace accidents are initially unwanted and unexpected events that can cause death and property (Permenaker, 1998). Workplace accidents are unexpected and original things that are not desirable, which interfere with the predetermined process of an activity and can cause damage to human victims and property (Indonesia, 1970). Accidents in the workplace are accidents that occur at work from the departure from home to office and return to home through normal or normal ways (Indonesia, 1992).

The term "informal sector" is usually used to indicate a number of small-scale economic activities. The informal sector in cities in particular must be seen as a smallscale unit involved in the production and distribution of goods that are still in the evolutionary process rather than considered as a group of small-scale companies with great (managerial) capital input and management (Sethurahman, 1997). Informal sector workers are workers who work in households or institutions / offices / companies / institutions that are not incorporated without state protection and skill level efforts are not taxed. The types of informal sector companies are home industries such as craftsmen, furniture makers, craftsmen shoes and sandals, welding shops and car motors.

The ILO (international of Labor Organization) defines the informal sector as a sector that is easy to enter by newcomer entrepreneurs using economic resources owned by small-scale groups, using customized technology, adapted skills, skills needed outside of school, unregulated government and engaged in competitive markets. Whereas according to the Central Statistics Agency, informal sector workers are those whose employment status is; first, try yourself. Second, trying with the help of household members / non-permanent workers. Third, free workers in agriculture, Fourth, non-agricultural free workers, Fifth, temporary workers/family workers. Informal workers in Indonesia are quite large (around $70 \%$ of the workforce) and are very widespread in all rural to urban areas. The cost of collecting costs will be very expensive and not worth the amount 
that can be collected. Candidates for Social Security participants with a workforce of 22 million formal workers, only around 9 million who actually regularly pay contributions every month (Adillah \& Anik, 2015).

The number of poor people (population per capita per month below the poverty line) in Indonesia reached 26.58 million (10.12 percent), decreasing by 1.19 million people compared to the conditions in March 2017 of 27.77 million people (10, 64 percent). In addition, the urban poor at 7.72 percent in March 2017 fell to 7.26 percent in September 2017. Meanwhile, the percentage of poor people in rural areas in March 2017 was 13.93 percent, down to 13.47 percent in September 2017 (BPJS, 2017).

The status of informal sector workers or workers who are not known as breadwinners still dominates the workforce in Indonesia, which is around 60.14 percent. The large number of workers is a potential membership of national health insurance. In 2016 there were 42.40 percent of the population working in the formal sector and 57.60 percent working in informal activities (Idris et al, 2015). In 2018, based on data from the Central Bureau of Statistics, it was stated that the number of workforce was 133.94 million, of which 73.98 million people (58.22 percent) worked in informal activities, which was a decrease of 0.13 percent compared to the year 2017.

In 2013, one worker in the world died every 15 seconds due to workplace accidents and 160 workers experienced work-related illnesses. The previous year recorded a total of 2 million work accidents and illnesses per year (ILO at the Ministry of Health, 2013). Recorded 6,000 fatal accidents in the world. Accident cases every day in Indonesia, one third come from the construction sector. The cause of the accident was triggered by a lack of education in the construction sector. Of the total workforce, there are 98-100 thousand cases each year with 121 million people (Rochmi, 2016).

Data from the Social Security Organizing Agency (BPJS) found in 2017 increased work accidents by around 20 percent compared to 2016 nationally with 123,041 cases with a claim value of $R p .971$ billion while 2016 is Rp. 792 billion more. This number continues to increase in 2018 to 173,105 cases with work accident insurance claims with a total claim of 1.2 trillion (Widianto, 2019). The main causes of accidents are still low awareness of the importance of the application of Occupational Safety and Health (K3) in industry and society. During the implementation of Occupational Safety and Health it is often considered a cost or workload, not as an investment to prevent accidents (Statistics, 2017). Occupational accidents in the vulnerable period of the year there are an average of 99,000 cases where 70 percent of them are fatal, namely death and disability for life. In 2013 there were 1 worker in the world who died every 15 seconds due to workplace accidents and 160 workers experienced work-related illnesses.

Informal sector workers in Thailand do not have employee status. They do not work at the employer's workplace; they work at home and may be self-employed or temporary workers. They are responsible for 62.6 percent of the Thai workforce and have a work accident rate ten times higher than formal workers (Kongtip, 2015). Informal construction workers in Pakistan consisting of 316 locations employing 3,566 construction workers find that both employers and workers do not have legal knowledge and occupational health and safety standards and workplace accidents, there is no concern and the system hurts official reports and this will result in huge costs (Ishfaq, et.al, 2017).

The coverage of health services in the informal sector does not have a health financing system. Labor can be assumed as a contributor to the high number of accidents originating from the informal sector. Informal sector workers generally have excessive workload and time, while labor wages are subpar. Sector entrepreneurs generally pay less attention to information about occupational health and safety rules (Icohis, 2009).

The high number of work accidents and illnesses caused by work in the informal sector needs special attention for the government and the private sector. As a prevention in workplace accidents and workrelated illnesses, the government has sought to make occupational health programs including the provision of social security (Social Security), which is now known as a Social Security Organizing Agency worker. However, payment of 
contributions and the amount of compensation payments that do not match the level of accidents at work.

Problems that can be drawn from the informal sector workforce are related to the number of occupational accidents that are still high and are not balanced with the number of employment collateral utilization benefits. Occupational accidents and workrelated illnesses are difficult to find out due to weak reporting so that it is deemed necessary to get attention. The Law on the National Social Security System clearly states that every workforce is required to take part in a work accident insurance program but is not fully supported by special attention to the informal sector given the relatively high number compared to the formal sector in Indonesia.

\section{METHODOLOGY}

This research was carried out by library study method. According to Zed (2008: 4-5), there are 4 characteristics of library research, namely 1) researchers are dealing with text or numerical data and not with direct knowledge from the field and witnesses; 2) library data is ready to use (readymade), meaning that researchers do not go anywhere except only dealing with source material that is already available in the library; 3) library data from secondary sources in the sense that the researcher obtains second hand material and not original data from first hand in the field; 4) that the condition of library data is not limited by space and time, because whenever the researcher returns, the data will not change because it has been stored in the written record. The subjects of this study are data in the form of articles and several source books related to the theme of the research, namely concerning workplace accidents and social security of informal sector workers in Indonesia.

\section{RESULTS}

The activities and implementation of occupational safety and health for workers in the formal sector are generally well implemented, while the informal sector is not yet known because of low reporting. Event work and the informal sector work very much and have not been classified based on the type of business, type of work, and workplace. Zero accidents that are targeted by the government need support from all parties and the need to increase the $K 3$ culture that still needs to be done. The government, institutions and industrial society are obliged to play an active role in accordance with their respective functions and authority to strive for occupational safety and health. The most appropriate effort in implementing $\mathrm{K} 3$ is through systems namely the occupational health safety management system (SMK3) (Indonesia, 2012).

Social Security is a state mechanism to overcome challenges in providing access and health care for citizens, especially the poor. Expansion of the benefits of health coverage in reducing cost constraints when accessing health services and protecting households from disasters and poverty due to health care costs (Idris et al, 2015). Social security is a basic human right and has risen sharply after the enactment of Law No. 40 of 2004 concerning the National Social Security System (Navigation). Social security is divided into two parts, namely long-term traits such as retirement, retirement, when violating work, and death and short libertine guarantees such as health insurance and personal accident. This form of social security financing social insurance can be imposed on residents or employers. Coercive payments for contributions, as well as payment of taxes, because the market mechanism (no implementation) fails to meet social security goals. Commercial insurance can only provide guarantees to be willing and able to buy it alone (Joni Emirzon, 2005: 9 in Yustisia, 2015).

The operation of social security in the social dimension is the principle of mutual cooperation both vertically between income that is different and horizontal between generations. Social security is also related to governance, governance and the relationship of institutionalization of the governing body and government institutions as regulators as well as facilitators of the implementation of sustainable social security. The implementation of the social security system is full of political intervention, public pressure and the government's political will. Funding the social security system involves all stakeholders including employers, recipients of work and the government. The key to success in implementing a social security system is the 
implementation of effective legal action. Inconsistency in law enforcement occurs when the limited budget is limited, the quality of labor inspectors is limited and the authority of the social security administration body is limited.

\section{Comparison of social security in Indonesia and other countries.}

Social security limits are in the form of assistance to answer the problems of illness, accident, birth, disability, health, death, absence of work done through insurance. The implementation of the social security system depends on economic conditions, the employment situation, the government's ability to create jobs, impose adequate wages and indicate work convenience, because the principle of work is based on sustainable work so that employment or permanent employment is a strong foundation for the organizing agency social security in expanding the participation of effective and sustainable social security systems.

When viewed from the level of insurance use in Indonesia, social security systems such as health in Indonesia are still inadequate. The use of insurance is still minimal. Learning from the social security system in several countries such as Germany, the United Kingdom, the United States, Thailand, China and Mongolia related to their social security system, especially their work accident insurance.

The social security system in Germany was pioneered by Otto van Bismarck namely by providing health insurance to certain groups of workers in accordance with the needs of industrialization. Insurance is required for the workers themselves and their employers (Shihab, 2013). In other words, the employer works together to finance social security programs through a social insurance mechanism. The new accident insurance law was approved in 1884 after the approval of the health insurance law. Germany made developments that were manifested in reforming the pattern of providing benefits to long-term unemployed people and recipients of social assistance but they still could not carry out accident insurance reform.

The first social security system in the UK has enacted a law with a health insurance scheme. Subsequently the first law on social security in England began in 1908 for old-age pensions, then followed by guarantees for individuals with disabilities in 1911 and 1925 for old-age survivor insurance. The current regulations are the 1992 consolidation legislation, the 1995 retirement law, the welfare reform and retirement in 1999, the support of children, retirement and social security in 2000 and the 2002 pension credit. All of these provisions regulate the provision of social security in the form of social insurance and social assistance.

The social security system in America is carried out with a single law and is organized by one government body (social security administration). The Social Security Act in the United States through the Social Security Act which covers seven programs, namely financing support for the elderly, social security for the elderly, social security for unemployment, welfare for children, funding for pregnant women and infants, public health programs, and financing for people who experience blindness. The emergence of social security in America is a manifestation of the industrial revolution. Before the industrial revolution most of the American population worked in fields as farmers or laborers.

Social security developed in Thailand first received its benefits, namely the Civil Servants, the military, and employees of government companies. The social security program in Thailand consists of a guarantee program for government employees, private employees and health programs. Thailand adopted the Labor Act of 1956 for the contingency of workplace accidents, deaths, health for workers. Protection for workers is further enhanced by the Ministerial Decree for 30 days of sick permission and pregnancy permits while still getting a salary. The protection of workers in workplace accidents is implemented for the Ministry of Manpower through the Workmen's Compensation Fund (WCF). This policy is an action to reward workers in the industrial and commercial fields. Health insurance and cash benefits are provided for workers who are sick or experience workplace accidents. Rehabilitation is also provided for workers with disabilities (Shihab, 2013)

Like Thailand, China is also one of the countries that has experienced a sharp increase in coverage of social security. The 
system is more comprehensive, such as protecting mothers, insurance and injuries at work. Every worker has an individual account. The scheme for protecting urban and rural residents is done differently and adapted to needs. Similar to China, Mongolia is also included in a country where the social security system is adequate and comprehensive, such as insurance, social security, child protection and insurance for slag herders because Mongolia is a lot of cattle herders. The poor in Mongolia are fully borne by the government in terms of social security such as health (Kusuma, 2015).

The nature of social security in Indonesia has existed since the beginning of independence, which is stated in the 1945 Constitution of the Republic of Indonesia which mandates the ideals of nation and state, namely social welfare for all Indonesian people. It is stated in Article $28 \mathrm{H}$ of the second amendment to the 1945 Constitution, paragraph 3, that "Every person has the right to social security which enables his full development as a dignified human being". Then from the fourth amendment to article 34 paragraph 2 also stated that "the State develops a National Social Security System for all people and empowers people who are weak and incapable in accordance with human dignity". The scheme of the National Social Security System (SJSN) in Indonesia gave birth to the 2004 SJSN Law and the 2011 BPJS Law. Law No. 40 of 2004 was enacted to extend social security to all Indonesian people.

Based on Law Number 24 of 2011 concerning BPJS, it is stated that there are two bodies that will handle social security in Indonesia, namely the health BPJS and Employment BPJS. This BPJS includes 5 Social Security programs namely Health Insurance implemented by BPJS Health, and Work Accident Guarantees, Pension Insurance, Old Age Guarantee, and Death Assurance carried out by BPJS Employment where specifically for Health Insurance, contributions to the poor are borne by the government.

The establishment of this BPJS will provide opportunities for all people to be actively involved, wherever they are, whatever their activities and work, regardless of their social status, whether rich or poor, will receive a health service guarantee program, pension, pension insurance, work accident insurance and life insurance according to what is described in Law No. 24 of 2011 concerning BPJS through payment of contributions.

\section{Occupational Accident Insurance for Informal Workers in Indonesia}

Workers' Social Security (Jamsostek) which is now transformed into the Manpower Social Security Organizing Agency is a form of social protection for workers provided by the government in accordance with the Law on the National Social Security System in Indonesia. The current social security program in Indonesia is for private employees, managed by the BPJS Employment while for the State Civil Service (ASN) managed by PT. Taspen and members of the TNI and POLRI are managed by PT. ASBRI. Where the scope of the employment social security program is one of them is an Accident Insurance. Social Security according to the ILO is a social security provided by the community not the state.

The number of JKK participants in informal sector workers based on 2017 Susenas data is 298,910 workers. This data is not comparable with the number of informal workers in Indonesia. There are many factors that influence the participation of the JKK ownership. Can be seen from the level of work risk and the direct benefits that are felt or received by the workers themselves.

BPJS Employment provides work accident insurance called the Work Accident Guarantee (JKK). JKK provides compensation and rehabilitation for workers who experience accidents in the period between leaving for work until arriving back home or suffering from diseases related to the implementation of their work. The coverage of participants guaranteed employment accidents can be estimated to be the same as the number of social security participants in the employment BPJS so that the percentage of participants is still less when compared with the number of workers in Indonesia, especially in the informal sector.

Participants in the Work Accident Guarantee program are classified into two, namely participants who receive wages and participants who are not wage earners. Classification which is intended to 
differentiate the way in which contributions are determined. Contributions for participants to receive wages are set at a certain percentage of wages, while contributions for non-wage participants are determined based on a certain nominal amount that is regularly reviewed by the government.

Informal sector workers fall into the category of workers not wage earners. Where the amount of contribution is set at $1 \%$ (one percent) which is deducted based on a certain nominal according to the ability of income set out in Appendix II of Government Regulation no. 44 of 2015, which means that contributions are fully borne by the participants.

Participants who are affected by an accident are entitled to work accident benefits in the form of: 1) changing transportation costs of participants who experience workplace accidents to hospitals and / or their homes, including costs of first aid in accidents, 2) health services in accordance with medical needs, 3) rehabilitation bandu and or dressing equipment for participants whose limbs are missing or not functioning due to workplace accidents, 4) temporary compensation unable to work or, 5) cash compensation paid at once.

Participants not wage recipients must register themselves with BPJS Employment according to the stages of participation. If you have a business or work more than 1 (One), the participant must include a description of the business activity or work in the registration form at the most 2 (two) types of work. For workers and informal business activities in accordance with the safety requirements and occupational health protection is very weak. Workers generally they (entrepreneurs / employees) only think of work and get money at the expense of their own safety and health, maybe also other people around them. Small accidents are considered natural, because of negligence. Occupational health and safety knowledge is passed on to subordinates or other employees, not only as a warning or defense training (Yani, 2006).

Implementation of Occupational Health Efforts (Occupational Health Efforts) is a health development strategy in the informal sector in Indonesia which includes promotive, preventive, curative, and rehabilitative services. UKK is a form of empowerment in groups of informal workers to protect workers to live healthy and free from health problems and the adverse effects of work (Ministry of Health, 2012).

Republic of Indonesia's Health Act No. 36 of 2009 concerning Health in Occupational Health Section XII Article 164 paragraph (1) states that occupational health efforts aim to protect workers for healthy living and free from health problems and adverse effects caused by work. The workspace manager must comply with the occupational health standards set by the government, to build a healthy work environment and be responsible for accidents. Furthermore, in Article 165, it is explained that health managers in the workplace must make every effort through prevention, care and recovery for the workforce, but together with workers in this case it is also responsible for maintaining the health of the workplace and compliance with applicable regulations in place work.

The implementation of social security programs for workers in the informal sector is a priority for workers outside the employment relationship that dominates the workforce in Indonesia. Implementation of this program, there are still obstacles, among others, the lack of cooperation between Jamsostek and Employment in the informal workers sector, lack of socialization, difficulty in contacting and finding the existence of workers independently, while in terms of labor, namely payment of contributions and the amount of compensation payments work accident rates (Adillah \& Anik, 2015).

Factors that hinder or become an obstacle in the application of occupational safety and health in developing countries are access to information on occupational safety and health is very limited, occupational safety and health knowledge at the manager and worker level is low, the safety equipment available in the market is very limited and of low quality, conflict regional, economic pressures, climatic factors and exchange of foreign exchange slightly complicate the implementation of occupational safety and health and the high number of workers while employment is small (Rosenstock, 2004).

Labor law states that every worker / laborer has the right to protection of health and safety, moral decency and is treated in accordance with inherent dignity and 
religious values. One of these rights is the application of occupational health and safety provided to protect the safety of workers / laborers in order to achieve optimal productivity. National health insurance is health protection for participants who receive health care and protection benefits to meet basic health needs, which are given to every person who has paid contributions or fees paid by the national government which is based on the principle of social insurance. Participants in the national social security system are everyone, including foreigners who work for a minimum of six months in Indonesia, who have paid contributions (Presidential, 2013). Contributions to be paid every month can be called premiums. Premium is the amount of money that must be paid every month as the obligation of the insured for his involvement in insurance (Witcahyo, 2016).

Thailand's labor law applies only to formal workers, but some protect informal workers in the domestic sector, home work, and agriculture. Laws that protect informal workers do not have a practical enforcement mechanism and are generally ineffective for informal workers who do not have employment contracts and awareness of their legal rights. The Thai social security law fails to provide accidents, illnesses and injuries to informal care workers related to work; unemployment and pension insurance; and worker compensation (Kongtip, 2015)

The unique characteristics of Indonesia provide different challenges in developing social protection systems compared to systems that have been developed in industrialized countries. We cannot rely solely on the government to provide social protection for poor and informal economic workers, given the limited financial resources owned by the government and the dominance of informal economy workers in the labor market.

Law no. 31992 Article 1 and 3 concerning social security, social security is protection for workers in the form of compensation in the form of money as a partial substitute and loss of income or reduction and service as a result of events or circumstances experienced by workers in the form of workplace accidents, diseases, pregnancy labor by workers in the form of workplace accidents, illness, pregnancy, maternity, old age and death. Article 34 paragraph 2 of the 1945 Constitution and its amendments state that the state develops a social security system for all citizens and empowers those who are weak and less capable of human dignity. According to Law No. 40 of 2004 concerning the Social Security program there are five types of social security provided by the government including health insurance, accident insurance, old age insurance, pension insurance and life insurance. Social Security is a form of social protection to ensure that everyone in order to meet basic life needs.

Law No. 24 of 2011 concerning the Agency for the implementation of social security states that the national labor social security system is a state program aimed at providing protection and social welfare for all citizens. To achieve these goals, it is necessary to establish institutions that regulate legal entities based on the principles of cooperation, non-profit, transparency, prudence, accountability, portability, mandatory membership and trust funds, and management of social security funds, full work for program development and for the maximum benefit of the participants.

Workers who carry out work outside the employment relationship, allow accidents, illness, pregnancy, birth and death and must receive protection through social security programs. Workers who carry out work outside the employment relationship have a certain specificity so that the social security protection program must be determined to implement a social security program for workers outside the employment relationship with ministerial regulations.

The biggest challenge now is how to expand social protection coverage for informal workers. In Indonesia, social security reform is driven by the enactment of Law No. 40 of 2004 concerning the National Social Security System (Navigation). About $17 \%$ of public workers have enjoyed official social security, especially those who work in the formal sector. Based on the survey it was found that around $80 \%$ of 2,068 informal workers did not have social security, no formal social security and no informal written social security apart from the family.

Participants from the informal employment sector have unique and diverse background characteristics with large populations, which are scattered in remote 
areas of Indonesia. Provision of health insurance for workers with termination of employment (PHK) of more than 6 months and diffables is still a discussion because the rules regarding the implementation of National Health Insurance have not been synchronized to regulate it. There is an ambiguous interpretation between the law regarding the determination of the criteria of the poor and needy, especially those who are laid off who are 6 months unemployed and permanently disabled (Laksmiarty in Intiasari, 2017).

Barriers to participation in informal sector workers have not been aware of the existence of labor social security programs, have not yet realized the importance of participating in social security programs, the amount to be paid each month, BPJS Employment HR Staff Facilities and facilities are inadequate. The results of the study related to the implementation of social security policies in Semarang, that the majority of respondents agreed with the statement about social entertainment that employment social security for informal sector workers must be the government's main work program to improve welfare. The factors that influence social security employment policies for the informal sector are the strong commitment of the government (political will) to encourage the growth of the number of participants through equity-based regulations. Informal sector operators need to grow following BPJS awareness of employment to improve their welfare. So that the collection collection results are allocated to encourage the growth of the informal sector, for example in the form of capital, training, skills, intensive training (Yustis, 2015).

\section{CONCLUSION}

The number of work accidents, especially in the informal sector in Indonesia still tends to be high, especially in construction work. Policies in the field of occupational health and safety (K3) still focus on formal sector workers rather than informal workers. The role of employment in the informal sector or independent work where workers who carry out work outside of work relations are increasing, accompanied by various challenges and risks they face. Therefore informal sector workers need to be provided with protection, maintenance and improvement of welfare which will increase national productivity.

The government needs to calculate contributions to informal sector workers related to social security adjusted for the level of accidents at work or work-related illnesses suffered by workers and the amount of costs associated with their ability to pay. There needs to be socialization regarding occupational safety and health policies and social security to informal workers.

\section{REFERENCE}

$B P S$, 2017. Keadaan angkatan kerja di Indonesia Agustus 2017:Labor force situation in Indonesia august 2017. Badan Pusat Statistik

Fitriana, Laela \& Wahyuningsih, Anik Setyo, 2014. Higiea: Application of Occupational Health and Safety Management System (SMK3) PT. Ahmadaris

Indonesia, 2013. Indonesia Presidential Decree number 111 of 2013 concerning amendments to the presidential decree number 12 of 2013 concerning health insurance.

Indonesia, 2012. Peraturan Pemerintah no. 50 tahun 2012 tentang penerapan sistem manajemn keselamatan dan kesehatan kerja.

Ishfaq Ahmed, et.al, 2017. Keselamatan kesehatan dan keselamatan di segmen ekonomi informal Pakistan: survei lokasi konstruksi. Artikel jurnal internasional keselamatan dan ergonomi kerja: JOSE 24 (13): 1-17Agustus 2017.

Icohis 2009 di Mindayani, S. 2012, Pengaruh Sikap Kerja terhadap Keluhan Muskoleskeletal di Tangan Bordir Kerajinan di Nagari Koto Gadang Sumatera Barat (tesis). Program S2 Studi IImu Kesehatan Masyarakat, Fakultas Kesehatan Masyarakat, Universitas Sumatera Utara.

Iwan M. Ramdan, Hanna Novita Handoko, 2017: Konstruksi Kecelakaan Kerja pada Pekerja Informal di Desa " $X$ " Samarinda. MKMI Journal, Vol. 12 No. 1, Maret 2016.

Intiasari, et al, 2017. premium strategi switching dalam pengumpulan dana masyarakat dari sektor 
informal untuk mencegah keterlambatan dalam pembayaran premi asuransi kesehatan nasional. Indonesia Journal of Public Health, Vol. 9 No 1, p. 6477, Januari 2017.

Indonesia, 1992. Undang-Undang no. 3 Tahun 1992 tentang Jaminan Sosial Tenaga Kerja.

Indonesia, 1970. Undang-Undang no. 70 Tahun 1970 tentang Keselamatan Kerja. Indonesia, prosedur Pelaporan 1998. dan kecelakaan pemeriksaan.

Kusuma, Dewi Rahmat, 2015. Belajar system jaminan sosial dari Thailand, Mongolia dan China. Diakses dari website https://finance.detik.com/moneter/d3012962/belajar-sistem-jaminansosial-dari-thailand-mongolia-danchina

Mulyani, Ani, 2012. K3 Industri Sektor Informal "pedagang martabak."

Pornpimol Kongtip. 2015. Pekerja Informal di Thailand: Kesehatan Disparitas dan Jaminan Sosial; Departemen Keselamatan dan Kesehatan Kerja, Fakultas Kesehatan Masyarakat, Universitas Mahidol, Bangbok, Thailand.

Rochmi, Muhammad Nur, 2016. Kecelakaan tertinggi sektor konstruksi.
Sethuraman, 1997, Kemiskinan Perkotaan dan Sektor Informal: Sebuah Penilaian Kritis Strategi Current (Jenewa, Organisasi Buruh Internasional).

Siti ummu adillah dan Sri Anik 2015. Kebijakan Jaminan Sosial Tenaga Kerja Sektor Berbasis Informal Keadilan Sosial untuk Meningkatkan Kesejahteraan; Jurnal Vol. 4 No. 3 SeptemberDesember 2015.

Shihab, Ahmad Nizar, 2013. BPJS Jalan Panjang Mewujudkan Sistem Jaminan Sosial Nasional (Central Informasi Networking Transformasi dan Aspirasi Indonesia).

Statistic Indonesia, 2017. www.bps.go.id

Widianto, Satrio, 2019. Kecelakaan Kerja 2018 Mencapai 173.105 Kasus. Diakses dari https://www.pikiranrakyat.com/nasional/2019/01/15/kece lakaan-kerja-2018-mencapai173105-kasus, februari 2019.

Yani, Muhammad, 2006. Keselamatan dan Kesehatan di tempat kerja di Sektor Informal-DK3N, Jakarta, 2006.

Zed, M. 2008. Metode Penelitian Kepustakaan. Jakarta: Yayasan Obor Indonesia. 